Виницкий Л.В., Бурносова Ю.Л.

ПРОБЛЕМНЫЕ ВОПРОСЫ РАССМОТРЕНИЯ УГОЛОВНОГО ДЕЛА В СУДЕ ПЕРВОЙ ИНСТАНЦИИ В ПОРЯДКЕ ГЛАВЫ 40 УПК РФ

Vinitskiy L.V., Burnosova Y.L.

\title{
PROBLEMIC ISSUES OF THE CONSIDERATION OF A CRIMINAL CASE IN THE COURT OF FIRST INSTANCE IN THE ORDER OF CHAPTER 40 OF THE RF CRIMINAL PROCEDURE CODE
}

Статья посвящена критическому анализу содержания главы 40 УПК РФ. Предлагается ознакамливать обвиняемого, согласного с предьявленным обвинением, не после ознакомления с материалами уголовного дела, а после допроса его в качестве обвиняемого. Предоставить право прокурору, а не только государственному обвинителю, выражать свое мнение о возможности рассмотрения уголовного дела в особом порядке.

Ключевые слова: глава 40 УПК РФ, следователь, прокурор, государственный обвинитель, потерпевший, судья, защитник.

The article is devoted to a critical analysis of the content of chapter 40 of the RF Criminal Procedure Code. It is proposed to acquaint the accused who agrees with the accusation, not after familiarizing himself with the materials of the criminal case, but after questioning him as an accused. Provide the right to the prosecutor, and not only the state prosecutor, to express his opinion on the possibility of considering a criminal case in a special order.

Keywords: chapter 40 of the Code of Criminal Procedure of the Russian Federation, investigator, prosecutor, public prosecutor, victim, judge, defender.

УПК РФ в главе 40 предусмотрел особый порядок рассмотрения уголовных дел о преступлениях небольшой и средней тяжести, когда имеет место факультативная непосредственность, при которой, в основном, не исследуются доказательства по уголовным делам, что существенно ускоряет и удешевляет судопроизводство.

Общепризнано, что появление в уголовном процессе процедур, направленных на упрощение и ускорение существующего порядка уголовного судопроизводства является общемировой тенденцией. В связи с этим представляет несомненный интерес рассмотреть отдельные положения главы 40 УПК РФ и практику ее применения, именно оценивая ее содержание в ранге упрощенного производства, благодаря которому оно должно быть существенно реформировано.

Суть производства сводится к тому, что обвиняемый вправе, при наличии согласия государственного или частного обвинителя и потерпевшего (если по делу есть потерпевший), заявить о согласии с предъявленным ему обвинением и ходатайствовать о постановлении приговора без проведения судебного разбирательства по уголовным делам о преступлениях небольшой и средней тяжести. Согласие должно быть с предъявленным обвинением, формой вины, мотивом совершения деяния, юридической оценкой содеянного и даже размером заявленного гражданского иска. При этом не играет роли рецидив совершенных преступлений, необходимость назначения наказания по совокупности преступлений или совокупности приговоров.

Обвиняемый вправе заявить ходатайство в момент ознакомления с материалами уголовного дела совместно с защитником, о чем делается соответствующая запись в протоколе ознакомления с материалами уголовного дела (ст. 217 УПК РФ). Однако по окончании дознания, в ч. 2 ст. 225 УПК РФ нет указания о необходи- 
мости разъяснения обвиняемому его права в установленных ст. 314 УПК РФ случаях заявить о согласии с предъявленным обвинением и ходатайствовать о постановлении приговора без проведения судебного разбирательства. Обязанность разъяснять участникам уголовного судопроизводства их права закреплена, в частности, в ст. 11 УПК РФ.

Заявляя ходатайство в момент ознакомления с материалами дела, обвиняемый еще не знает ни о согласии с этой процедурой государственного или частного обвинителя, ни о согласии потерпевшего.

Тем не менее, ходатайство о применении особого порядка судебного разбирательства может быть удовлетворено лишь в случае, если оно заявлено до назначения судебного заседания в присутствии защитника при согласии государственного или частного обвинителя, потерпевшего, других обвиняемых. Следует отметить, что УПК РФ не определяет, как и в каком процессуальном документе досудебного производства, согласие вышеперечисленных субъектов должно быть зафиксировано, когда и как об этом узнает обвиняемый [1, с.284]. ст. 37 УПК РФ, устанавливающей полномочия прокурора, как стороны обвинения, как и в ст. 226 УПК РФ, определяющей действия и решения прокурора по уголовному делу, поступившему с обвинительным заключением или с обвинительным актом, тоже - и в ст. 246 УПК РФ, устанавливающей обязательное участие государственного обвинителя в судебном разбирательстве, ничего не говорится о том, когда и как названный субъект должен заявить о своем согласии на рассмотрение дела и постановление приговора в особом порядке.

Проблема заключается и в том, что потерпевший не всегда знакомится с материалами законченного расследованием уголовного дела, а только в случаях заявленного им ходатайства (ч. 1 ст. 216 УПК РФ). Причем это ознакомление по закону происходит до знакомства обвиняемого и его защитника с материалами уголовного дела. Поэтому потерпевший и не знает о желании обвиняемого рассмотреть материалы уголовного дела в порядке главы 40 УПК РФ в особом порядке.

Прокурор, утверждая обвинительное заключение, направляет уголовное дело в суд, о чем уведомляет обвиняемого и его защитника, потерпевшего и разъясняет им право заявить ходатайство о проведении предварительного слушания (4. 1 ст. 222 УПК РФ). Однако, как видно из изложенного, закон его не обязывает никому из них сообщать о своем отношении к ходатайству обвиняемого.

Закон обязывает государственного обвинителя, а не прокурора, сообщить о своем отношении к ходатайству обвиняемого (ст. 314 УПК РФ). Однако государственный обвинитель появляется в процессе с момента назначения уголовного дела к слушанию. При проведении предварительного слушания присутствует прокурор, а еще не государственный обвинитель (ч. 4 ст. 235 УПК РФ).

Ходатайство обвиняемого может быть заявлено после направления уголовного дела с обвинительным заключением или обвинительным актом в суд в течение 3 суток со дня получения копии обвинительного заключения или обвинительного акта, обвинительного постановления на предварительном слушании. Форма ходатайства законом не регламентирована и поэтому считается, что оно может быть заявлено обвиняемым письменно или устно с отражением в протоколе. Обращает на себя внимание тот факт, что УПК РФ не предусматривает обязательного проведения предварительного слушания для назначения судебного разбирательства в особом порядке.

Таким образом, назначая дело к слушанию в порядке главы 40 УПК РФ, судья тоже еще не знает позицию государственного обвинителя и потерпевшего. Поэтому данное решение следует признать предварительным (условным). Если в ходе подготовительной части судебного заседания потерпевший (при условии его явки) и государственный обвинитель заявят о своем согласии, то дело будет рассмотрено в особом порядке. При наличии возражений, судья будет вынужден вынести постановление о рассмотрении дела в общем порядке. Но участники уголовного судопроизводства к этому моменту не вызваны. Они должны быть извещены о дате и времени судебного заседания не менее чем за 5 суток до его начала (ч. 4 ст. 231 УПК РФ). Так что рассмотрение дела в общем порядке будет рассмотрено в новые сроки.

Изложенное позволяет прийти к выводу о необходимости совершенствования процессуального законодательства в этой части. Представляется, что следователь должен разъяснять обвиняемому его право ходатайствовать о рассмотрении уголовного дела о применении особого порядка судебного разбирательства (и все особенности данного производства) не после ознакомления с материалами уголовного дела, а перед допросом, что позволяет проинформировать его о про-
81

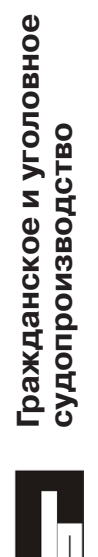


цессуальных возможностях. Правовая норма в этом случае будет стимулирующей. Или после допроса обвиняемого, когда становится ясно, что он, после проведения консультаций с защитником, согласен с предъявленным обвинением.

В этом случае у следователя появляется возможность информировать потерпевшего о ходатайстве обвиняемого и выяснить, при каких условиях он согласен на рассмотрение уголовного дела в особом порядке без проведения судебного разбирательства. Если потерпевший заявит какие-либо условия, то у обвиняемого появится время их выполнить или отказаться от заявленного ходатайства.

Следует законодательно закрепить право прокурора выражать свое отношение к ходатайству обвиняемого о рассмотрении уголовного дела в порядке главы 40 УПК РФ. Такое дополнение необходимо внести в п. 3.1 ч. 1 ст. 221 УПК РФ, указав «о согласии на рассмотрение уголовного дела в порядке главы 40 УПК РФ». Это позволит исключить ту неопределенность, с которой в наши дни сталкивается суд, принимая решение о назначении уголовного дела к слушанию в особом порядке без исследования материалов уголовного дела, не имея данных о позиции потерпевшего и государственного обвинителя.

По делам частного обвинения, при наличии оснований для назначения судебного заседания, мировой судья должен разъяснить в судебном заседании подсудимому права, предусмотренные ст. 47 УПК и, в частности, право на заявление ходатайства об особом порядке судебного разбирательства по делам данной категории в соответствии с ч. 3 ст. 319 УПК, хотя об этом прямо не упоминается ни в ст. 47, ни в ст. 319 УПК. С момента принятия судом заявления к своему производству, лицо, его подавшее, является частным обвинителем. Ему должны быть разъяснены права, предусмотренные статьями 42 и 43 УПК (ч. 7 ст. 318 УПК).

Представляется, что особо сложной проблемой является решение вопроса о достоверности согласия обвиняемого с предъявленным обвинением, поскольку мог иметь место самооговор обвиняемого, воздействие на него с помощью угроз, различных советов, рекомендаций с чьей-либо стороны. А ведь бывает и так, что начальная, и вроде бы очевидная, версия оказывается ложной. При детальном исследовании доказательств в судебном процессе вполне может выясниться, что человек виновен лишь частично, либо вообще получить оправдательный приговор [2].

В связи с изложенным, мы убеждены в том, что ст. 316 УПК РФ должна быть дополнена требованием допроса подсудимого, по аналогии со ст. 317.7 УПК, в которую Федеральным законом от 03.07.2016 г. № 322-Ф3, после многочисленных публикаций, была внесена часть 3.1, предусматривающая допрос подсудимого. Это позволит в ходе судебного заседания сторонам и судье непосредственно выяснять не только признает ли свою вину подсудимый, но и соответствие его показаний фактическим обстоятельствам дела, характер и размер причиненного преступлением вреда, не имеет ли место в данном случае самооговор и мн.др.

В этом случае, правила непосредственности и устности будут оставаться в силе в отношении допроса подсудимого, что позволитисключить Из ст. 240 УПК РФ выражение: «за исключением случаев, предусмотренных разделом X настоящего Кодекса» и, таким образом, правила непосредственности и устности будут стержневыми понятиями всего действующего судебного разбирательства, что чрезвычайно важно при построении правового государства.

\section{Литература}

1. Судебное производство в уголовном процессе Российской Федерации. Практическое пособие по применению Уголовно-процессуального кодекса РФ. - М.: ЮРАЙТ, 2008. - С. 284.

2. Кучерена А.Г. Правосудие и никаких сделок! // Российская газета. 20.01.2015. - № 8 (6519).

\section{References}

1. Sudebnoye proizvodstvo v ugolovnom protsesse Rossiyskoy Federatsii. Prakticheskoye posobiye po primeneniyu Ugolovno-protsessual'nogo kodeksa RF. - M.: YURAYT, 2008. - P. 284.

2. Kucherena A.G. Pravosudiye i nikakikh sdelok! // Rossiyskaya gazeta. 20.01.2015. - № 8 (6519). 
ВИницкий Лев Витальевич, доктор юридических наук, профессор, профессор кафедры уголовного процесса, криминалистики и судебной экспертизыЮжно-Уральского государственного университета. 454080, г.Челябинск, ул. Коммуны, д. 149. E-mail: Vin200839@yandex.ru

БУРНОСОВА Юлия Львовна, помощник судьи Смоленского областного суда. 214001, г. Смоленск, пр. Гагарина, д. 23. E-mail: viniyulya@yandex.ru

VINITSKY Lev Vitalievich, Doctor of Law, Professor, Professor of the Department of Criminal Procedure, Forensic Science and Forensic Science, South Ural State University. 454080, Chelyabinsk, st. Commune, 149. E-mail: Vin200839@yandex.ru

BURNOSOVA Yulia Lvovna, assistant judge of the Smolensk Regional Court. 214001, Smolensk, Gagarin Ave., 23. E-mail: Vin200839@yandex.ru 